\title{
Choose Celebrity or Common People? The Influence of Endorser Type on Instagram User's Purchase Intention
}

\author{
Virginia Vionasafira $^{1}$, Bertina Sjabadhyni ${ }^{2 *}$ \\ ${ }^{1,2}$ Faculty of Psychology, Universitas Indonesia, Depok, Indonesia \\ *E-mail: virginia.vionasafira@ui.ac.id
}

\begin{abstract}
This study aimed to examine whether purchase intention based on online consumer analysis was higher than based on micro-celebrity endorsement on Instagram and whether purchase intention based on microcelebrity analysis was higher than based on micro-celebrity endorsement and online consumer review on Instagram. The celebrity studied in this study was micro-celebrity on Instagram that was a new phenomenon especially in Indonesia. This study used online experimental method between-subjects design where the endorser type was varied between three groups (micro-celebrity endorsement, online consumer review, micro-celebrity review). The participants of this study were 540 women Instagram user aged 18-25 years old. The result showed that the average score of purchase intention on online consumer review group was significantly higher than micro-celebrity endorsement, $t(358)=-2,20$. Meanwhile, average score of purchase intention on micro-celebrity review was not significantly higher than microcelebrity endorsement and online consumer review on Instagram $t(537)=0,86, p>.05$ (1-tailed). Thus, we found that purchase intention based on online consumer review was higher than micro-celebrity endorsement. However, purchase intention based on micro-celebrity review was not higher than microcelebrity endorsement and online consumer review on Instagram. This result can be used as a basis for determining appropriate marketing strategy, especially on Instagram.
\end{abstract}

Keywords: micro-celebrity endorsement; micro-celebrity review; online consumer review; online experiment; purchase intention

\section{Introduction}

Indonesia is listed as a country with the largest internet user growth in the world with 132.7 million in numbers (We Are Social, 2017). The increase in internet usage later also resulted in increasing number of people shopping online that reached 24.74 million (We Are Social, 2017). That growing number of online shopping activities is due to fast consumer service, faster access to online stores, and the ease of making purchases even more as it is facilitated with mobile phones.

Given the increase in online shopping, e-commerce in Indonesia in 2017 is predicted to increase from previous year to 108.4 trillion rupiahs (Katadata, 2016). Online shopping can be facilitated by multiple platforms. However, the dominant online shopping market is in social media platform where the number of transactions reaches 2.7 million per day (Gaw, 2016). Shopping transaction using social media is perceived as a fast and efficient process among Indonesian consumers. The popular social media today as an online shopping platform is Instagram. Instagram users are known to access Instagram every day and when accessing Instagram, they mostly browse online stores on Instagram (JakPat, 2016). Instagram is considered to boost more sales compared to other social media (Desreumaux, 2015). Moreover, the ads displayed on Instagram can drive online shopping (Priambada, 2016).

Instagram emphasizes the visual features where users can easily upload creative photos or videos. The other facilities offered are commenting features to interact with fellow users, such as button to like other Instagram user uploads, explore features to easily view other user uploads, tagging features to help search photos and or videos, and more. Instagram developed its features in online shopping activities area, which facilitated entrepreneurs and consumers online shopping needs. Nowadays, entrepreneurs can easily upload photos and videos for promotions and those photos and videos can automatically appear on all Instagram users' 
timeline. Instagram users as potential consumers who see and are interested can open the photo or video and automatically directed to the official store website of the entrepreneur.

Seeing the dynamics of online shopping in Instagram, inevitably the online market competition in Instagram becomes increasingly tight. As a result, entrepreneurs need to think about the most beneficial marketing strategy to compete in the market. The goal is to attract the attention of consumers to increase sales of products or services for sustainability of its business. It is important for entrepreneurs to know what factors influence online shopping behavior on Instagram. The common way used to predict consumer shopping behavior is by measuring consumer purchase intention.

Many experts have already postulated definitions of purchase intention. Of all the existing definitions, we concluded that purchase intention is the tendency of the consumer to plan, attempt, or be willing to make a purchase transaction in the future after he evaluates the product or service. Purchase intention can illustrate the consumer's response to buying what the entrepreneur offers (Bhakar, Bhakar, \& Dubey, 2015). Purchase intention is known to have a positive relationship with the actual buying behavior. It means that the higher the purchase intention, the higher the actual purchase behavior will occur (Bhakar et al., 2015; Dodds, Monroe, \& Grewal, 1991; Schiffman \& Kanuk, 2000; Wang, Cheng, \& Chu, 2013). Therefore, purchase intention is valued as an important indicator in predicting consumer spending behavior, particularly actual buying behavior (Wu, Yeh, \& Hsiao, 2011).

Looking at the tight market competition, it is important for entrepreneurs to know what factors can improve consumer purchase intention. One strategy that plays a significant role in competing in the market is by promoting or advertising to attract attention and develop a positive consumer association of products or services (Khatri, 2006). Promotion and advertisement may motivate consumers to buy or increase the purchase intention. One marketing strategy that is considered effective in influencing shopping behavior, especially purchase intention, is the technique of celebrity endorsement (Bhakar et al., 2015; Spry, Pappu, \& Cornwell, 2011).

Celebrity endorsement is a marketing technique in which celebrities allow an entity such as a brand, a product, and others to use their name in promoting or supporting the entity (Bergkvist \& Zhou, 2016). This celebrity endorsement is proven to affect purchase intention (Gupta, Kishore, \& Verma, 2015; McCormick, 2016; Pornpitakpan, 2004; Wang et al., 2013). Celebrity endorsements are now rampant in the online world (Wood \& Burkhalter, 2014) where one of the most popular media for celebrity endorsements is Instagram. Celebrity endorsement in Instagram has become popular since the rise of Instagram celebrities, which will be referred to as a micro-celebrity, which often provides endorsement. The micro-celebrity is a non-traditional celebrity which differs from traditional celebrities such as movie stars, writers, musicians, sports icons, hosts, actors, and others who have been famous in the mass media (Chahal, 2016; Setiawan, Pratama, Ihsanudin, \& Prabowo, 2016). Micro-celebrity is a celebrity who was born in digital world where she actively presents herself by utilizing technology to increase her popularity on Instagram (Senft, 2008; Marwick, 2015).

The micro-celebrity is preferred by potential customers as she often uploads interesting photos or videos and easier to interact with her followers (Setiawan et al., 2016). This micro-celebrity is also highlighted by entrepreneurs because of her fantastic value due to her influence on followers and the cost of using her services for endorsement is not as big as traditional celebrities (Setiawan et al., 2016). However, there is another factor that can influence and be judged to be more influential in purchasing intention than celebrity endorsements in online context, which is common consumer review or online consumer review (Lee \& Youn, 2009).

Maximizing internet utilization, consumer review can now spread easily and quickly through online media (Lee \& Youn, 2009). Online consumer review is one form of electronic word-of-mouth (eWOM). E-WOM is defined as any statement both positive and negative to a product and or service made by the consumer using online media (HennigThurau, Gwinner, Gwalsh, \& Gremler, 2004). Other commonly used e-WOM names are User-Generated Content (UGC) or online consumer review. Several previous studies have also examined the effect of eWOM on purchase intention (Bataineh, 2015; Park, Lee, \& Han, 2007). A potential consumer who wants to purchase something can enrich their knowledge of a product or service by reading reviews given by experienced consumers. Reviews from fellow consumers are considered to be more 
trusted and credible because they are perceived as someone that doesn't have sales motive and provide actual information based on experience (Lee \& Youn, 2009).

Some entrepreneurs who have Instagram accounts offering products or services are often found to repost their consumer reviews. Consumers in Instagram also can view various other consumer reviews in one Instagram account. Along with the reviews given, consumers typically include a photo when they use the product or the various changes that occur after they have used certain products. Experienced consumers often provide product usage suggestions.

In addition to the micro-celebrity on Instagram endorsement and online consumer review, researcher's observation as an Instagram user resulted in that many micro-celebrity now also acts as experienced consumer who provides review of a product or service. Along with the review, she also uploads photos or videos when using a product or service. This is different from the previous one where the micro-celebrity as celebrity in general only post information contents that focus only on the advantages and description of the advertised product or service. We see this phenomenon as a new marketing strategy used by entrepreneurs and marketers.

As we mentioned before that micro-celebrity on Instagram provides review on a new phenomenon of marketing strategy, we did the preliminary study to validate our observation. We conducted Focus Group Discussion (FGD) to eight participants in total from Faculty of Psychology and Law with the same criteria as this study's participants. We asked about their micro-celebrity and micro-celebrity endorsement on Instagram content knowledge. The result pointed out that micro-celebrity indeed gave the review of a product, especially a product that could not be assessed directly by them (e.g., makeup, skin care product). Micro-celebrities themselves attracted them because of their creative Instagram posts and their reviews were more interesting rather than marketing content. They even wanted to try the product in stores. Besides the review, they would be more interested if the content was also the solution of daily obstacles or related to daily activities. It was perceived more natural and close to their daily life.

Looking at the phenomenon of the review given by the micro-celebrity, the researchers suspected that the strategy could affect purchase intention over two other factors explained earlier. This is based on the content of consumer review itself is considered more credible and reliable because it explains specifically the consumer experience when using a product or service. Moreover, that reviews were created and uploaded by the micro-celebrity as consumer on their Instagram personal account whichhad influenced her followers on Instagram because she was judged as trusted sources (Korotina \& Jargalsaikhan, 2016). This is a new phenomenon, especially in Indonesia. Although the microcelebrity reviews have never been directly tested for its impact on purchasing intention, previous studies have examined other forms of micro-celebrity on Blog or referred to as blogger (Lu, Chang, \& Chang, 2014). Bloggers reviews influence purchase intention because consumers have positive attitudes toward that bloggers. Although bloggers were paid by the entrepreneurs or marketers in making reviews, potential consumers still believe in them because they thought that bloggers were trusted.

Based on prior explanation regarding microcelebrity and online consumer review, we could see there are three factors that can affect consumer purchase intention on Instagram: micro-celebrity endorsement, online consumer review, and microcelebrity review. However, we have not found any empirical testing of the direct comparison of the three factors or endorser type influence on purchase intention on Instagram. The previous study only tested the comparative influence of celebrity endorsement and online consumer review on shopping behavior (Wei \& Lu, 2012). The results revealed that online consumer review significantly impacted memories, searches, and shared aspects of experience goods products which what prior study used was toner.

Therefore, the question arises whether the purchase intention based on online consumer review is higher than micro-celebrity endorsement on Instagram and whether the purchase intention based on microcelebrity review is higher compared to microcelebrity endorsement and online consumer review on Instagram. We assumed that the purchase intention based on online consumer review was higher than micro-celebrity endorsement on Instagram. Therefore the following hypothesis was developed:

H1. The average score of purchase intention on online consumer review is significantly higher than micro-celebrity endorsement on Instagram. 
We also added micro-celebrity review as a third group which we believed was a mixed form of micro-celebrity endorsement and online consumer review so it would increase purchase intention more compared to other groups, so the following hypothesis was developed:

H2. The average score of purchase intention on micro-celebrity review is significantly higher than micro-celebrity endorsement and online consumer review on Instagram

The result of the study can be used as a basis for determining the most beneficial endorser type to increase purchase intention for marketing strategy on Instagram.

\section{Methods}

Sample. This study's participants were 540 women Instagram user aged 18-25 years old. The sampling method used in this study was convenience sampling. We recruited participants by announcing the research link on social media from May 8 to 15 , 2017. Prior filling out the survey, participants would be required to fill an informed consent. Incomplete surveys would be eliminated from analysis.

Research Design. This study used between subjects post-test only experimental design, using three experimental groups. The endorser type was varied into micro-celebrity endorsement, online consumer review, and micro-celebrity review. Participants were given post-test to measure their purchase intention.

Instrument and Measurement. This study used purchase intention instrument adapted from McCormick study (2016). The instrument consists of 3 items which one example is: "I will probably buy the product" and was measured by 5 points Likert scale ranging from point 1 which was "Very unlikely" to point 5 which was "Very likely". Reliability measurement result showed that the purchase intention instrument is reliable $(\alpha=0,89)$.

Procedure. Before the experiment, a preliminary study using online survey was conducted to determine a suitable micro-celebrity for Instagram and suitable products to the micro-celebrity for endorsement. The preliminary study's participants were 70 female undergraduate students in Faculty of Psychology Universitas Indonesia and third-grade students in 87 Senior High School South Jakarta. Participants were asked about which micro-celebrity on Instagram they liked and considered famous, and what kind of products suitable for endorsement by their chosen micro-celebrity on Instagram. The results showed that the most frequently named micro-celebrity on Instagram and the highest frequency product suitable for her is Rachel Vennya and lipstick. This micro-celebrity on Instagram was used for both micro-celebrity endorsement and micro-celebrity review groups. The difference between both of them was the message content on caption box.

Micro-celebrity endorsement caption content was taken from one of the marketing content captions on Instagram and micro-celebrity review was taken from other micro-celebrities' lipstick review on Instagram. For the online consumer review, we created the same review as the micro-celebrity using common consumer identity.

We also made a fictional brand name to avoid participants' prior experience with the brand. The number of likes for both micro-celebrity on Instagram stimulus was based on the number of likes of the last photo updated by Rachel Vennya at the time. The number of likes for common consumer was made much lower from micro-celebrity. Then we asked a professional graphic designer to create ad with Instagram smartphone version view.

After all the stimulus were ready, we distributed the online survey link. The participants who clicked on the survey's link were randomly led to one of the three treatments. Each participant was asked to view the stimulus ad and fill in the questions below the ad. Afterwards, they were asked some questions related to manipulation check, participant's demographic data, and debriefing. The participants had the opportunity to get reward in the form of cash, Go-Pay balance or lipstick.

The pictures below are the stimulus of each group. 
Picture 1.
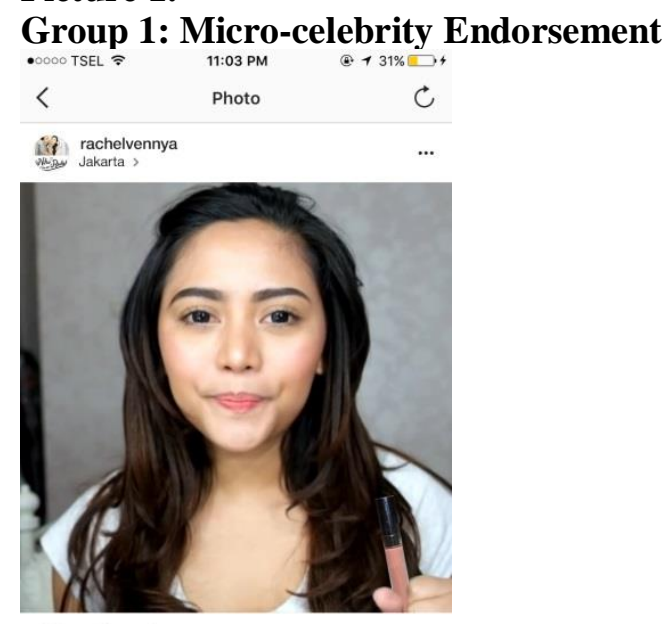

$\mathrm{OQC}$

- 158,149 likes

rachelvennya Lipcream Matte dari @lappstiftID ini terbuat dari formula yang membuatnya tahan lama dan terasa ringan, Lipstik ini sangat berpigmen dan kamu. Membuat tampilanmu semakin eye-catchy setiap harinya. Sudahkah kamu pakai Lipstik dar @lappstiftID ?

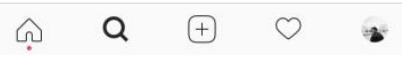

Picture 2.

Group 2: Online Consumer Review

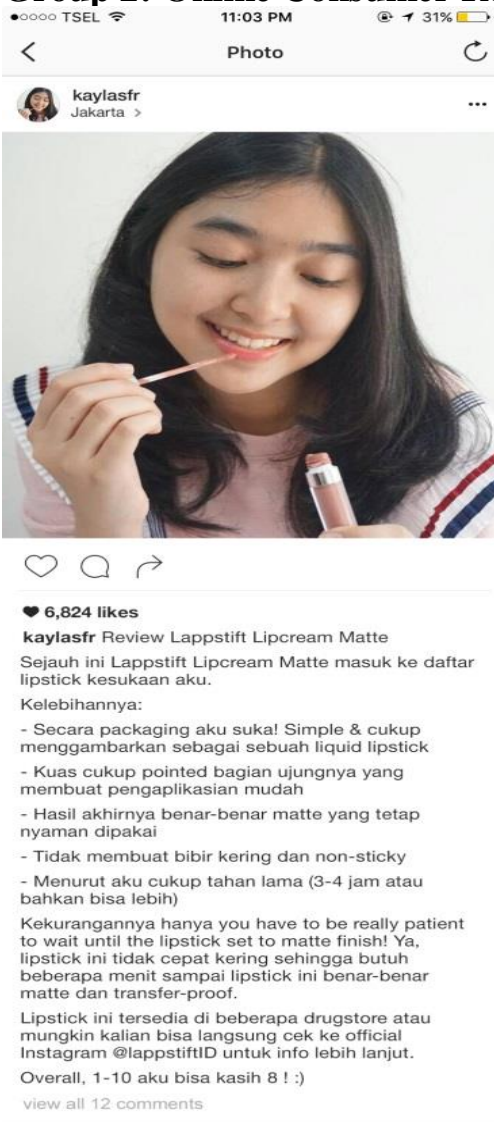

๑ $0 \oplus 0$
Picture 3.

Group 3: Micro-celebrity Review

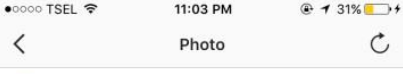

ifi rachelvennya

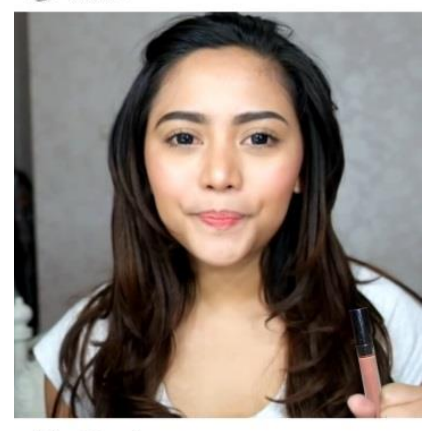

O Q

- 158,149 likes

rachelvennya Review Lappstift Lipcream Matte Sejauh ini Lappstift Lipcream Matte masuk ke daftar Kelebihannya:

- Secara packaging aku sukal Simple \& cukup
menggambarkan sebagai sebuah liquid lipstick - Kuas cukup pointed bagian ujungnya yang membuat pengaplikasian mudah

- Hasil akhirnya benar-benar matte yang tetap

- Tidak membuat bibir kering dan non-sticky - Menurut aku cukup tahan lama (3-4 jam atau Kekurangannya hanya you have to be really patie to wait until the lipstick set to matte finish! Ya.
lipstick ini tidak cepat kering sehinga butuh beberapa menit sampai lipstick ini benar-benar matte dan transfer-proof.

Lipstick ini tersedia di beberapa drugstore atau mungkin kalian bisa langsung cek ke official Overall, 1-10 aku bisa kasih 8! :)

vien at 12 con an

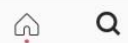

\section{Results}

The survey period started from May 8 to May 15, 2017. The number of participants was 540 distributed into three experimental groups. All of the participants were women in the age range of 1825 (25,4\% were 20 years old), $40,4 \%$ accessed Instagram from one to three hours per day, and 93,1\% were college students. Manipulation check results showed that participants in each group $100 \%$ knew the micro-celebrity on Instagram and $100 \%$ did not know the girl in the online consumer review ads.

Independent Sample T-test was used to measure the difference of the purchase intention on online consumer review and micro-celebrity review average score. Based on t-test, purchase intention on online consumer review group $(\mathrm{M}=8.90, \mathrm{SE}=$ $0.014)$ was significantly higher than on microcelebrity endorsement $(\mathrm{M}=8.30, \mathrm{SE}=0.015), t$ $(358)=-2.20, p=0.03$. 
Table 1.

The Average Score of Purchase Intention of Each Experimental Group

\begin{tabular}{lccc} 
Groups & $\boldsymbol{M}$ & $\boldsymbol{S D}$ & $\boldsymbol{n}$ \\
\hline $\begin{array}{l}\text { Micro-celebrity } \\
\begin{array}{l}\text { Endorsement } \\
\text { Online Consumer }\end{array}\end{array}$ & 8.26 & 2.70 & 180 \\
$\begin{array}{l}\text { Review } \\
\text { Micro-celebrity }\end{array}$ & 8.88 & 2.68 & 180 \\
Review & 2.77 & 180 \\
Total & 8.40 & 2.73 & 540 \\
\hline
\end{tabular}

We also compared the average score of purchase intention of each experimental group. As we can see from the table above, between the three experimental groups, the highest average scores of purchase intention among all were online consumer review $(M=8.90, S D=2.68)$.

Table 2.

One Way ANOVA Result

\begin{tabular}{lccccc}
\hline \multicolumn{1}{c}{ Source } & $\boldsymbol{d} \boldsymbol{f}$ & $\boldsymbol{S S}$ & $\boldsymbol{M S}$ & $\boldsymbol{F}$ & $\boldsymbol{p}$ \\
\hline Between & & & & & \\
Groups & 2 & 63.9 & 31.9 & 4.3 & $\mathbf{. 0 1 *}$ \\
& & & & & \\
Within Groups & 537 & 3974. & 7.4 & & \\
Total & 539 & 4038.54 & & & \\
\hline
\end{tabular}

The table above showed that overall, there were significant differences on average scores of purchase intention of the micro-celebrity endorsement, online consumer review, and microcelebrity review groups $[F(2,537)=4,31, p=$ 0.01]. Furthermore, the results of comparative analysis using planned contrasts indicated that the purchase intention based on micro-celebrity review is not significantly different the compared to microcelebrity endorsement and online consumer review $t(537)=0.86, p>.05$ (1-tailed).

\section{Discussion \& Conclusion}

Discussion. The results of this study indicate that purchase intention based on online consumer review is significantly higher than micro-celebrity endorsement on Instagram. The finding is in line with previous studies that online consumer review influences purchase intention (Bataineh, 2015; Fan \& Miao, 2012; Jalilvand \& Samiei, 2012; Park et al., 2007). Also, it supports why consumer's review, in this case, common people, has positive impact to potential consumer because their reviews are considered to be more reliable and credible and it can affect purchase intention compared to information obtained from celebrities (Lee \& Youn, 2009). Often celebrities provide endorsement using information content that has been created by marketers in which it usually focuses on the advantages and product descriptions. Consumers who have experienced using a particular product are judged to provide useful and complete information about their experience and what they think when using a product (Park et al., 2007). Experienced consumers also provide recommendations that make it easy for potential customers to make purchases.

The product type also influences why the average score of purchase intention on online consumer review group is higher than with the micro-celebrity endorsement. The product type of this study is lipstick and it could not be assessed quickly by consumers or usually referred to as an experience good. It can be said that lipstick is difficult to assess before potential customers try it themselves (Wei \& $\mathrm{Lu}, 2013)$. Furthermore, the gender under study is woman that could also influence the purchase intention especially when the type of product is an experience good. According to Wei and Lu (2013), women are more sensitive to and avoid the risks that may occur in the future when they want to purchase something. The risk is susceptible to experience goods because of the lack of product-related information. These things make potential customers more likely to seek more information about the products they want to buy through experienced consumers to facilitate purchase decision.

Also, micro-celebrity on Instagram also provides endorsement and reviews to various entities on Instagram, which can lead potential customers to think that the review given is a form of cooperation with entrepreneurs or marketers. It might be the reason why the purchase intention based on microcelebrity review is not significantly higher than other two groups.

This study is using a new type of celebrity for endorser type, which is micro-celebrity, which has not been studied extensively in previous studies. For future studies, we suggest to examine the characteristics of micro-celebrity that can affect consumer purchase intentions such as source credibility. Source credibility is known to affect consumer purchase intention. 
This study has several methodological issues such as not including manipulation check regarding the content of caption on each stimulus. Manipulation check needs to be included to see the effect of information content or how it is perceived by the participants.

Based on FGD results, information in the caption provided by micro-celebrity could also include a daily life story or showing that the product could solve a problem. These information could attract potential customers because it is close to customers' personal lives rather than just focus solely on presenting facts of the product. Also, it would provide more booster if micro-celebrity also gives decent and appropriate photos and or videos to support the product, besides information.

The results of this study could give practical knowledge for entrepreneurs or marketers that are willing to use endorsement as a strategy to attract potential consumers. Marketing techniques using eWOM could affect consumers more than microcelebrity endorsement and micro-celebrity review. Entrepreneurs or marketers should consider the use of e-WOM in which common people give a product review, especially on Instagram context.

Conclusions. Overall, the result showed that the purchase intention on online consumer review group was significantly higher than the purchase intention score on micro-celebrity endorsement. We also added micro-celebrity review for the second study for another comparison to the two previous groups and the result showed the micro-celebrity review did not have a higher average score than the other micro-celebrity endorsement and online consumer review groups. Also, the purchase intention on online consumer review is the highest among the other two groups.

\section{References}

Bataineh, A. Q. (2015). The impact of perceived e-WOM on purchase intention: The mediating role of corporate image. International Journal of Marketing Studies, 7(1), 126.

Bergkvist, L., \& Zhou, K. Q. (2016). Celebrity endorsements: a literature review and research agenda. International Journal of Advertising, 35(4), 642-663.

Bhakar, S., Bhakar, S., \& Dubey, A. (2015). Analysis of the factors affecting customers' purchase intention: The mediating role of customer knowledge and perceived value. Advances in Social Sciences Research Journal, 2(1).
Chahal, M. (2016). Four trends that will shape media in 2016. Marketing Week. Accessed from on https://www.marketingweek.com/2016/01/08/fourtrends-that-will-shape-media-in-2016/ on 2017, February 23

Desreumaux, G. (2015). Instagram is now the most influential social marketing platform. Accessed from http://wersm.com/instagram-is-now-the-mostinfluential-social-marketing-platform/ on 2017, April 12

Dodds, W. B., Monroe, K. B., \& Grewal, D. (1991). Effect of price, brand, and store information on buyer's product evaluations. Journal of Marketing Research, 28(3), 307-319.

Fan, Y. W., \& Miao, Y. F. (2012). Effect of electronic word-ofmouth on consumer purchase intention: The perspective of gender differences. International Journal of Electronic Business Management, 10(3), 175.

Gaw, M. (2016). Fintech talk: Maintaining market share of social commerce. Accessed from http://www.thejakartapost.com/news/2016/12/28/finte ch-talk-maintaining-market-share-of-socialcommerce.html on 2017, May 1

Gravetter, F. J., \& Forzano, L. B. (2009). Research Methods for The Behavioral Sciences ( $3^{\text {rd }}$ ed.). California: Wadsworth, Cengage Learning.

Gupta, R., Kishore, N., \& Verma, D. P. S. (2015). Impact of celebrity endorsements on consumers' purchase intention. Australian Journal of Business and Management Research, 5(3), Accessed from https://search.proquest.com/docview/17614116\%2031 ?accountid $=17242$ on 2017, April 12

Hennig-Thurau, T., Gwinner, K. P., Walsh, G., \& Gremler, D. D. (2004). Electronic word-of-mouth via consumeropinion platforms: what motivates consumers to articulate themselves on the internet?. Journal of Interactive Marketing, 18(1), 38-52.

JakPat. (2016). Indonesia social media trend 2016 jakpat. Retrieved from

https://www.slideshare.net/JAKPATAPP/indonesiasocial-media-trend-2016-jakpat on 2017, March 23

Jalilvand, R. M., \& Samiei, N. (2012). The effect of electronic word of mouth on brand image and purchase intention: An empirical study in the automobile industry in Iran. Marketing Intelligence \& Planning, 30(4), 460-476.

Katadata. (2016). Transaksi e-commerce Indonesia naik 500\% dalam 5 tahun. Accessed from http://databoks.katadata.co.id/datapublish/2016/11/16/ transaksi-e-commerce-indonesia-naik-500-dalam-5tahun on 2017, April 23

Khatri, P. (2006). Celebrity endorsement: A strategic promotion perspective. Indian Media Studies Journal, 1(1), 2537.

Korotina, A., \& Jargalsaikhan, T. (2016). Attitude towards Instagram micro-celebrities and their influence on 
consumers' purchasing decisions. Journal of Marketing, 72(2), 81-85.

Marwick, A. E. (2015). Instafame: Luxury selfies in the attention economy. Public Culture, 27(1 75), 137-160.

Lee, M., \& Youn, S. (2009). Electronic word of mouth (eWOM) How eWOM platforms influence consumer product judgement. International Journal of Advertising, 28(3), 473-499.

Lu, L. C., Chang, W. P., \& Chang, H. H. (2014). Consumer attitudes toward blogger's sponsored recommendations and purchase intention: The effect of sponsorship type, product type, and brand awareness. Computers in Human Behavior, 34, 258266.

McCormick, K. (2016). Celebrity endorsements: Influence of a product-endorser match on millennials attitudes and purchase intentions. Journal of Retailing and Consumer Services, 32, 39-45.

Park, D. H., Lee, J., \& Han, I. (2007). The effect of online consumer reviews on consumer purchasing intention: The moderating role of Involvement. International Journal of Electronic Commerce, 11(4), 125-148.

Pornpitakpan, C. (2004). The effect of celebrity endorsers' perceived credibility on product purchase intention: The case of Singaporeans. Journal of International Consumer Marketing, 16(2), 55-74.

Priambada, A. (2016). Survei DailySocial: Iklan Facebook dan Instagram berperan besar dalam mendorong keputusan berbelanja online di Indonesia. Accessed from https://dailysocial.id/post/survei-dailysocialiklan-facebook-dan-instagram-berperan-besar-dalammendorong-keputusan-berbelanja-online-diIndonesia on 2017, May 11

Schiffman, L. G., \& Kanuk, L. L. (2000). Consumer behaviour (7th ed.). New York: Prentice Hall.

Senft, T. M. (2008). Camgirls: Celebrity and community in the age of social networks. New York: Peter Lang.
Setiawan, T. S., Pratama, A. M., Ihsanudin, \& Prabowo, D. (2016). Selebgram: menguak layar bisnis selebgram. Accessed from http://vik.kompas.com/selebgram/ on 2017, April 2

Spry, A., Pappu, R., \& Bettina Cornwell, T. (2011). Celebrity endorsement, brand credibility, and brand equity. European Journal of Marketing, 45(6), 882-909.

Wang, J. S., Cheng, Y. F., \& Chu, Y. L. (2013). Effect of celebrity endorsements on consumer purchase intentions: advertising effect and advertising appeal as mediators. Human Factors and Ergonomics in Manufacturing \& Service Industries, 23(5), 357367.

We Are Social. (2017). Digital in 2017: Global overview. Retrieved from https://wearesocial.com/specialreports/digital-in-2017-global-overview on 2017, April 25

Wei, P. S., \& Lu, H. P. (2013). An examination of the celebrity endorsements and online customer reviews influence female consumers' shopping behavior. Computers in Human Behavior, 29(1), 193

Wood, N. T., \& Burkhalter, J. N. (2014). Tweet this, not that: A comparison between brand promotions in microblogging environments using celebrity and company-generated tweets. Journal of Marketing Communications, 20(1-2), 129-146.

Wu, P. C., Yeh, G. Y. Y., \& Hsiao, C. R. (2011). The effect of store image and service quality on brand image and purchase intention for private label brands. Australasian Marketing Journal (AMJ), 19(1), 30-39 